\title{
PHYSICAL ACTIVITY AND MEDICATION IN THE CONTROL OF BLOOD PRESSURE: SECONDARY ANALYSIS OF THE BRAZILIAN NATIONAL HEALTH RESEARCH
}

\section{Atividade física e medicação no controle da pressão sanguínea: análise secundária da pesquisa nacional de saúde}

\author{
Clarissa Biehl Printes ${ }^{\mathrm{a}}$ (1), Fabiane de Oliveira Brauner ${ }^{\mathrm{a}}$ (1), Ângelo José Gonçalves Bós ${ }^{\mathrm{a}}$ (1)
}

AIM: To test the effectiveness of different physical activities (PA) in controlling blood pressure. The dependent variable was controlled and uncontrolled blood pressure (BP). METHODS: This is a secondary analysis of a cross-sectional, observational, descriptive and analytical study from the Brazilian National Health Research (PNS) database. The PNS was conducted by the Brazilian Institute of Geography and Statistics (IBGE) in 2013, in partnership with the Ministry of Health. Total PA was calculated in minutes per week (MPS) with the sum of 3 activities, physical exercise, time spent walking to work, and heavy work activity. Sociodemographic variables and the use of $\vdash$ hypertension medications were analyzed as possible associated factors. RESULTS: The chances of having controlled BP were calculated by logistic regression. Among the 10199 participants aged 40 years and older, who reported hypertension, 5398 (53\%) had controlled BP, being higher among the women (56\%), within the age range of 40-59 years-old (56\%), and on medication for hypertension (54\%). The controlled-BP group performed $64 \pm 146.1$ MPW of PA while the uncontrolled-BP spent $46 \pm 150.7$ MPW in PA ( $p<0.001)$. Work activity was also higher among the controlled-BP group $(p=0.019)$. Participants who performed total PA between 90-149 MPW had $21 \%$ higher odds of controlled-BP ( $p=0.024)$ and those who performed $150 \mathrm{MPW}$ or more, $22 \%(p=0.001)$. Medication increased the chance of BP control by $18 \%$ ( $p=0.003$ ). The odds of having controlled-BP were higher in physical exercise: $42 \%$ on 90-149 MPW $(p=0.001)$ and $40 \%$ on 150 MPW or more ( $<$ 0.001). CONCLUSION: Physical exercise was significantly associated with better BP control than just total PA. Both exercise and total physical activity were significantly associated with better BP control than medication. KEYWORDS: physical exercise; population; arterial pressure.

OBJETIVO: Testar a efetividade de diferentes atividades físicas (AF) no controle da pressão arterial. A variável dependente foi a pressão arterial (PA) controlada e não controlada. MÉTODOS: Trata-se de uma análise secundária de um estudo transversal, observacional, descritivo e analítico de um banco de dados da Pesquisa Nacional de Saúde (PNS). A PNS foi conduzida pelo Instituto Brasileiro de Geografia e Estatística (IBGE), no ano de 2013, em parceria com o Ministério da Saúde. A AF total foi calculada em minutos por semana (MPS) com a soma de três atividades, exercício físico, tempo gasto na caminhada para o trabalho e atividade laboral pesada. As variáveis sociodemográficas e o uso de medicamentos para hipertensão foram analisados como possíveis fatores associados. RESULTADOS: As chances de controlar a PA foram calculadas por regressão logística. Entre os 10.199 participantes, com 40 anos ou mais, que relatam hipertensão, 5.398 (53\%) controlavam a PA, sendo maior entre as mulheres (56\%), com idade entre 40 e 59 anos (56\%) e em uso de medicamentos para hipertensão (54\%). O grupo PA controlado realizou 64 \pm 146,1 MPS de AF, enquanto o PA não controlado passou $46 \pm$ 150,7 MPS em AF ( $p$ <,001). A atividade laboral também foi maior no grupo PA controlado ( $p=0,019)$. Os participantes que executaram AF total entre 90-149 MPS tiveram chances $21 \%$ mais altas de pressão controlada $(p=0,024)$ e 150 MPS ou mais, essa probabilidade foi de $22 \%(p=0,001)$. A medicação aumentou a chance de controle da PA em 18\% ( $p=0,003)$. As chances de ter PA controlada foram maiores no exercício físico: 42\%, em 90-149 MPS ( $p=0,001$ ) e 40\% em 150 MPS ou mais ( $p<0,001$ ). CONCLUSÃO: O exercício físico esteve significativamente associado a um melhor controle da PA do que somente a prática de AF total. Tanto o exercício físico quanto a atividade física total mostraram-se significativamente associados a um melhor controle da PA do que a medicação.

PALAVRAS-CHAVE: exercício físico; população; pressão arterial.

aPontifícia Universidade Católica do Rio Grande do Sul - Porto Alegre (RS), Brazil.

Corresponding data

Fabiane de Oliveira Brauner - Pontifícia Universidade Católica do Rio Grande do Sul - Avenida Ipiranga, 6.681, sala 81 - CEP: $90619-900$ - Porto Alegre (RS), Brazil. E-mail: fabiane.oliveira@edu.pucrs.br

Received on: 09/01/2019. Accepted on: 11/12/2019

DOI: $10.5327 / 22447-212320191900056$ 


\section{INTRODUCTION}

The World Health Organization set as a goal to be achieved by developing and developed countries, in the coming decades, to commit to combating and controlling longterm noncommunicable diseases (NCD) by adopting the paradigm "compression of morbidities" ${ }^{1}$ Hypertension is a high prevalence health condition with significant increase in recent years. The condition was raised from the 16 th position in the global mortality ranking in 2000 to the 10 th position in 2012. ${ }^{2}$ The Brazilian Institute of Geography and Statistics (IBGE) estimates that $21.4 \%$ of Brazilian adults are hypertensive. This estimate is higher among people over 40, with low education, living in urban areas and in the Southeast Region ${ }^{3}$. Data from the Brazilian Ministry of Health's Hypertension and Diabetes Registration and Monitoring System also point out as risk factors for hypertension in the Brazilian population: advanced age, obesity, smoking, alcohol consumption, and ethnicity (Afro-Brazilians). The diagnosis of this condition is basically established by the association of permanently elevated BP levels above normal $(140 \mathrm{mmHg}$ by $90 \mathrm{mmHg}){ }^{4}$ Therefore, the most important diagnostic criterion in the routine verification of blood pressure (BP).

Hypertension is characterized as a silent disease, since in most cases it is asymptomatic. The main goal of treatment of high BP is to reduce cardiovascular mortality by maintaining BP within normal limits. The Brazilian Society of Cardiology and the Brazilian Ministry of Health consider 4 major lifestyle modifications for controlling BP: weight reduction, smoking cessation, healthy eating, moderate consumption of alcohol, and physical activity (PA). ${ }^{5,6}$

Caspersen et al. distinguish the terms physical activity and physical exercise. It is common to classify as PA the movement resulting from the contraction of skeletal muscles causing energy expenditure above resting levels, including work and leisure activities. ${ }^{7}$ Exercise is a planned, structured and repetitive PA that has as a final goal the improvement of components of physical fitness. ${ }^{7}$ The Brazilian Health Survey (BHS), conducted by IBGE in partnership with the Ministry of Health in 2013, observed different aspects of lifestyle, including PA, and the characteristics of NCD, including hypertension. ${ }^{8}$ Through the BHS microdata, which is freely available at the IBGE website, it is possible to identify the participants with diagnostic of hypertension, different types of PA (including physical exercise, time commuting on foot, and heavy labor activity) and the $\mathrm{BP}$ measured 3 times during the survey. Thus, the data allows the identification of those hypertensive participants who have controlled blood pressure (CBP) and their lifestyle.

In this sense, it is important to know, through the analysis of a population-based data, the possible effect of different PA in the control of BP, adjusting for sociodemographic characteristics and medication use. Then, this would provide Public Health Policies for hypertension treatment and control.

This is a secondary analysis, a cross-sectional, observational, descriptive and analytical study from a National Health Research (PNS) database. The PNS was conducted by the Brazilian Institute of Geography and Statistics (IBGE), in 2013, in partnership with the Ministry of Health.

\section{METHOD}

The project of PNS was approved by the National Committee for Ethics in Research of the National Health Council by Opinion number 328159.

Participants were randomly selected by census sectors in the North, Northeast, South, Southeast, and Midwest regions of Brazil. Initially, IBGE researchers visited more than 60 thousand households, selecting an 18-year-old resident for a comprehensive health evaluation. Details on the sampling methodology and evaluation instrument were published by the IBGE in 2015..$^{8-10}$ For the present analysis, we included the data of all interviewees, aged 40 years or over, who reported having a diagnosis of hypertension (answered, "yes” for the question Q002 — "Have any doctors diagnosed arterial hypertension?"). The dependent variable was the presence of CBP: systolic $<140 \mathrm{mmHg}$ and diastolic $<90 \mathrm{mmHg}$, dichotomously classified as Yes or No. Physical activities were divided into physical exercise, performed at leisure time (walking, gym, cycling, swimming, and sport); commuting (time spent for walking or cycling to work, round trip); heavy labor activity (time spent on heavy labor activity). Total PA computed as the sum of the 3 activities - physical exercise, commuting, and heavy labor activity - expressed in minutes per week (MPW). Sociodemographic variables were analyzed as possible associated factors (gender, age, race, schooling, and marital status) and the use of hypertension medication. The Epi Info ${ }^{\text {TM }} 7$ statistical software was used for the analyses. Initially, descriptive analyses (Chi-square and Student's $t$ tests) observed the possible significant associations or differences between controlled or not controlled blood pressure participants. Significant factors in the descriptive analyses were included in 2 different Logistic Regression models: with total physical activity level and with physical exercise level. Significance was established at $\mathrm{p}<0.05$.

\section{RESULTS}

Among the 10199 participants, who reported having received the diagnosis of hypertension in the BHS, 5398 (53\%) had CBP (Table 1). ${ }^{11}$ Among the 6,556 hypertensive 
women (64\%), 3,656 (56\%) had CBP, a percentage that was higher than the percentage of men (48\%). This association was significant $(p<0.001)$. Participants aged 40 to 59 years had a higher percentage of $\mathrm{CBP}(56 \%)$, and those participants aged 80 or older, the lowest percentage $(46 \%, p<0.001)$. There was a significant association between skin color and CBP $(\mathrm{p}<0.001)$.

Table 1 Distribution of demographic, life-style, and treatment characteristics between hypertensive participants with controlled and uncontrolled blood pressure.

\begin{tabular}{|c|c|c|c|c|}
\hline & No & Yes & Total & $\mathrm{p}$ \\
\hline \multicolumn{5}{|l|}{ Sex } \\
\hline Female & $2,900(44.2 \%)$ & 3,656 (55.8\%) & $6,556(64.3 \%)$ & \multirow{2}{*}{$<0.001$} \\
\hline Male & 1,901 (52.2\%) & $1,742(47.8 \%)$ & $3,643(35.7 \%)$ & \\
\hline \multicolumn{5}{|l|}{ Age group (years-old) } \\
\hline $40-<59$ & 2,209 (44.1\%) & 2,804 (55.9\%) & $5,013(49.2 \%)$ & \multirow{3}{*}{$<0.001$} \\
\hline $60-<79$ & 2,203 (49.3\%) & 2,268 (50.7\%) & 4,471 (43.8\%) & \\
\hline 80 and older & 389 (54.4\%) & $326(45.6 \%)$ & 715 (7.0\%) & \\
\hline \multicolumn{5}{|l|}{ Color } \\
\hline White & 2,005 (41.8\%) & 2,457 (45.5\%) & 4,462 (43.7\%) & \multirow{4}{*}{$<0.001$} \\
\hline Brown & $2,163(47.7 \%)$ & $2,372(52.3 \%)$ & 4,535 (44.5\%) & \\
\hline Black & $556(52.3 \%)$ & $506(47.7 \%)$ & $1,062(10.4 \%)$ & \\
\hline Other & 77 (55.0\%) & $63(45.0 \%)$ & $140(1.4 \%)$ & \\
\hline \multicolumn{5}{|l|}{ Marital Status } \\
\hline Married & 2,559 (46.0\%) & 3,001 (54.0\%) & 5,560 (54.5\%) & \multirow{4}{*}{0.0474} \\
\hline Divorced & $633(46.8 \%)$ & 719 (53.2\%) & 1,352 (13.3\%) & \\
\hline Single & $638(48.0 \%)$ & $691(52.0 \%)$ & $1,329(13.0 \%)$ & \\
\hline Widowed & 971 (49.6\%) & $987(50.4 \%)$ & 1,958 (19.2\%) & \\
\hline \multicolumn{5}{|l|}{ Schooling } \\
\hline Illiterate & $1,028(55.3 \%)$ & $832(44.7 \%)$ & $1,860(18.2 \%)$ & \multirow{5}{*}{$<0.001$} \\
\hline Incomplete Elementary & $2,214(48.5 \%)$ & $2,348(51.5 \%)$ & $4,562(44.7 \%)$ & \\
\hline Complete Elementary & 496 (47.5\%) & 549 (52.5\%) & 1,045 (10.3\%) & \\
\hline High School & $706(41.1 \%)$ & $1,013(58.9 \%)$ & $1,719(16.9 \%)$ & \\
\hline College or higher & 357 (35.2\%) & $656(64.8 \%)$ & $1,013(9.9 \%)$ & \\
\hline \multicolumn{5}{|l|}{ Medication for Hypertension } \\
\hline No & $794(51.1 \%)$ & $760(48.9 \%)$ & $1,554(15.2 \%)$ & \multirow{2}{*}{$<0.001$} \\
\hline Yes & 4,007 (46.3\%) & $4,638(53.7 \%)$ & $8,645(84.8 \%)$ & \\
\hline Physical Exercise (min/w) & $45.8 \pm 150.67$ & $63.8 \pm 146.12$ & $55.3 \pm 148.54$ & $<0.001$ \\
\hline Labor Activity (min/w) & $61.8 \pm 244.18$ & $65.9 \pm 225.15$ & $64.0 \pm 234.30$ & 0.019 \\
\hline Walk to work $(\mathrm{min} / \mathrm{w})$ & $16.7 \pm 38.20$ & $15.5 \pm 34.47$ & $16.0 \pm 36.28$ & 0.637 \\
\hline \multicolumn{5}{|l|}{ Physical activity level } \\
\hline Inactive & $2,300(50.1 \%)$ & 2,293 (49.9\%) & $4,593(45.0 \%)$ & \multirow{4}{*}{$<0.001$} \\
\hline $1-89 \mathrm{~min} / \mathrm{w}$ & $1,082(48.8 \%)$ & $1,136(51.2 \%)$ & $2,218(21.8 \%)$ & \\
\hline $90-149 \mathrm{~min} / \mathrm{w}$ & $301(42.8 \%)$ & $402(57.2 \%)$ & 703 (6.9\%) & \\
\hline$\geq 150 \mathrm{~min} / \mathrm{w}$ & $1,118(41.6 \%)$ & $1,567(58.4 \%)$ & $2,685(26.3 \%)$ & \\
\hline Total & $4,801(47.1 \%)$ & 5,398 (52.9\%) & 10,199 (100\%) & \\
\hline
\end{tabular}

Min/w: minutes per week.

Source: NHS (2013). ${ }^{11}$ 
The highest percentage of $\mathrm{CBP}$ was for afro-descendants (52\%) and the lowest percentage was for white individuals (46\%) and the other skin colors (45\%). Marital status had a significant association $(\mathrm{p}=0.04)$, married participants presented the highest percentage of $\mathrm{CBP}(54 \%)$ and widowers presented the lowest percentage (50\%). We observed a progressive increase of the percentage of CBP according to the rising of the school level $(p<0.001)$. Illiterate had the lowest percentage of CBP $(45 \%)$. Among participants using medication for Hypertension, 54\% had CBP, while for those without medication this percentage was $49 \%(\mathrm{p}<0.001)$.

Among the different physical activities studied, physical exercise was the one that presented the greatest difference between hypertensive participants with and without CBP. On average, participants with $\mathrm{CBP}$ performed on average $64 \pm 146.1 \mathrm{~min}$ utes of physical exercise per week and those without CBP, the mean was $46 \pm 150.7$ minutes per week $(p<0.001)$. The mean of minutes of heavy labor activity was also higher among those with $\operatorname{CBP}(p=0.019)$. The average time spent on walking to work was not significantly different between the 2 groups $(p=0.637)$. Among the levels of total physical activity (sum of all weekly activities), the higher the weekly time spent in activity, the greater was the CBP $(p<0.001)$. While $50 \%$ of the inactive group presented CBP, among those performing 150 minutes or more per week this frequency was $58 \%$.

Table $2^{11}$ presents the odds of presenting CBP, adjusted for socio-demographic factors, total physical activity level, and use of hypertension medications. The chance of CBP was $30 \%$ lower in males than females ( $p<0.001)$. Compared with participants aged 80 years and over, younger age groups had significantly higher rates of CBP. In participants within the age range 40-59 years, adjusted odds of presenting CBP were $30 \%$ higher $(\mathrm{p}=0.003)$, and in those within the age range $60-79$, the odds were $14 \%$ higher, but not significant $(p=0.127)$. Although the White participants presented lower percentage of CBP than the other skin-colors in the descriptive, unadjusted analysis; in the adjusted analysis the other races showed less chances of CBP. Both Black (odds ratio $=0.80,95 \% \mathrm{CI} 0.70-0.92, \mathrm{p}=0.002)$ and the other skin-colors $(0.67,95 \% \mathrm{CI} 0.47-0.94, \mathrm{p}=0.019)$, presented significantly lower odds of CBP than the White. Compared to married participants, those with other marital statuses had lower chances of CBP, but none remained significant in the adjusted analysis. All schooling levels presented significantly higher odds of having CBP compared to illiterate participants. Higher education level was a factor associated with a 2-fold increase in the chances of CBP, compared to illiterate participants in the adjusted analysis. Compared to the inactive participants, the other levels of physical activity had greater chances of CBP. The odds of CBP for participants who performed between 90 and 149 minutes per week were $21 \%(p=0.024)$ and those with 150 minutes or more of physical activity were $22 \%(\mathrm{p}=0.001)$. Medication use increased the chance of CBP by $18 \%(p=0.003)$.

The distribution of participants with and without $\mathrm{CBP}$ and weekly exercise levels is presented in Table $3 .{ }^{11}$ As in total physical activity, participants with higher levels of weekly physical exercise had a higher percentage of CBP $(p<0.001)$. Participants who practiced between 90 and $149 \mathrm{~min} / \mathrm{w}$ and $150 \mathrm{~min} / \mathrm{w}$ or more of physical exercise presented respectively 61 and $62 \%$ of CBP.

Table $4^{11}$ presents the results of the logistic regression model for CBP adjusted for sociodemographic characteristics, physical exercise level, and the use of hypertension medications. The odds of CBP remained significant for sex, age, skin color,

Table 2 Odds of presenting controlled blood pressure by sociodemographic characteristics, physical activity, and the use of medication for hypertension.

\begin{tabular}{|c|c|c|c|}
\hline & Odds Ratio & $95 \% \mathrm{Cl}$ & $\mathbf{p}$ \\
\hline \multicolumn{4}{|l|}{ Sex (Reference: Female) } \\
\hline Male & 0.70 & $0.64-0.76$ & $<0.001$ \\
\hline \multicolumn{4}{|c|}{ Age group (Reference: $\geq 80$ years old) } \\
\hline $40-<59$ years old & 1.30 & $1.10-1.55$ & 0.0027 \\
\hline $60-<79$ years old & 1.14 & $0.96-1.34$ & 0.1272 \\
\hline \multicolumn{4}{|l|}{ Color (Reference: White) } \\
\hline Brown & 0.94 & $0.87-1.03$ & 0.1778 \\
\hline Black & 0.80 & $0.70-0.92$ & 0.0015 \\
\hline Other & 0.66 & $0.47-0.94$ & 0.0193 \\
\hline \multicolumn{4}{|c|}{ Marital Status (Reference: Married) } \\
\hline Divorced & 0.91 & $0.81-1.03$ & 0.1473 \\
\hline Single & 0.91 & $0.81-1.03$ & 0.1537 \\
\hline Widower & 0.90 & $0.80-1.06$ & 0.0896 \\
\hline \multicolumn{4}{|c|}{ Schooling (Reference Illiterate) } \\
\hline Incomplete Elementary & 1.23 & $1.10-1.37$ & 0.0003 \\
\hline Complete Elementary & 1.24 & $1.07-1.45$ & 0.0078 \\
\hline High School & 1.59 & $1.38-1.83$ & $<0.001$ \\
\hline College or higher & 2.02 & $1.71-2.38$ & $<0.001$ \\
\hline \multicolumn{4}{|c|}{ Physical Activity (Reference: Inactive) } \\
\hline $1-89 \mathrm{~min} / \mathrm{w}$ & 1.04 & $0.94-1.15$ & 0.4787 \\
\hline $90-149 \mathrm{~min} / \mathrm{w}$ & 1.21 & $1.02-1.42$ & 0.0244 \\
\hline$\geq 150 \mathrm{~min} / \mathrm{w}$ & 1.22 & $1.10-1.35$ & 0.0001 \\
\hline $\begin{array}{l}\text { Medication for } \\
\text { Hypertension }\end{array}$ & 1.18 & $1.06-1.32$ & 0.0031 \\
\hline
\end{tabular}

Source: NHS (2013). ${ }^{11}$

95\% Cl: 95\% confidence interval; min/w: minutes per week. 
schooling, and medication use. Marital status also maintained statistical non-significance. When compared with the adjusted model for the level of total physical activity, the adjusted odds of presenting CBP were higher using physical exercise levels. Participants, performing less than 90 minutes per week of physical exercise, had $12 \%$ higher adjusted odds of having CBP, although not significant $(p=0.258)$. For other levels of physical exercise, the adjusted odds were $42 \%$ for participants with dedication from 90 to $149 \mathrm{~min} / \mathrm{w}(\mathrm{p}=0.001)$ and $40 \%$ higher for participants with dedication of $150 \mathrm{~min}$ or more per week ( $p<0.001$ ). The chance of having CBP for the use of hypertension medication decreased in this model to $16 \%(\mathrm{p}=0.008)$.

\section{DISCUSSION}

Over the past 5 decades, the enhancement of physical fitness and exercise management for hypertension was relevant. Studies showed that BP significantly decreases with the practice of dynamic exercises. However, few studies demonstrate the possible difference between exercise and physical activity. ${ }^{10,12}$ The main results obtained by this analysis showed that, for hypertensive participants, physical exercise and physical activity are related to CBP. The longer the weekly time spent on activity, the greater the chances of having CBP.In addition, both physical exercise and physical activity showed a greater tendency for CBP than medication use, and this chance is even greater through physical exercise. The analyses also found that being a woman, being young, using hypertension medications, and having a high level of education increased the odds of CBP.

An active lifestyle has been described as a protective factor for hypertension. As shown in experimental studies in hypertensive patients, regular aerobic exercise results in a significant decrease in BP.In the present study, among the different physical activities studied, exercise was the one that presented the greatest difference between hypertensive participants with and without CBP. Paffenbarger et al. ${ }^{13}$ and Fagard ${ }^{14}$ demonstrated that less active people seem to be at an increased risk of 30 to 50\% for high BP. The American College of Sports Medicine recommends the practice of 150 minutes of regular physical activity per week at a moderate intensity of 40 to $60 \%$ of maximum capacity for hypertensive and diabetic patients as well as those with metabolic syndrome. This recommendation is related

Table 4 Odds to present controlled blood pressure by sociodemographic characteristics, Physical Exercise, and the use of medication for hypertension.

\begin{tabular}{|c|c|c|c|}
\hline & Odds ratio & $95 \% \mathrm{Cl}$ & p \\
\hline \multicolumn{4}{|c|}{ Sex (Reference: Female) } \\
\hline Male & 0.69 & $0.6284-0.7469$ & $<0.001$ \\
\hline \multicolumn{4}{|c|}{ Age group (Reference: $\geq 80$ years old) } \\
\hline $40-<59$ years old & 1.31 & $1.1041-1.5620$ & 0.002 \\
\hline $60-<79$ years old & 1.13 & $0.9559-1.3295$ & 0.155 \\
\hline \multicolumn{4}{|c|}{ Color (Reference: White) } \\
\hline Brown & 0.95 & $0.8699-1.0338$ & 0.228 \\
\hline Black & 0.80 & $0.6984-0.9204$ & 0.002 \\
\hline Other & 0.67 & $0.4761-0.9447$ & 0.022 \\
\hline
\end{tabular}

Marital Status (Reference: Married)

\begin{tabular}{l|l|l|l}
\hline Divorced & 0.91 & $0.8070-1.0307$ & 0.140 \\
\hline Single & 0.93 & $0.8180-1.0480$ & 0.223 \\
\hline Widowed & 0.90 & $0.8009-1.0126$ & 0.079 \\
\hline
\end{tabular}

Schooling (Reference Illiterate)

\begin{tabular}{l|c|c|c}
\hline Incomplete Elementary & 1.22 & $1.0907-1.3635$ & $<0.001$ \\
\hline Complete Elementary & 1.22 & $1.0409-1.4268$ & 0.014 \\
\hline High School & 1.56 & $1.3528-1.7929$ & $<0.001$ \\
\hline College or higher & 1.91 & $1.6095-2.2569$ & $<0.001$ \\
\hline
\end{tabular}

Physical Exercise (Reference inactive)

\begin{tabular}{l|c|c|c}
\hline $1-89 \mathrm{~min} / \mathrm{w}$ & 1.12 & $0.9211-1.3575$ & 0.258 \\
\hline $90-149 \mathrm{~min} / \mathrm{w}$ & 1.42 & $1.1455-1.7683$ & 0.001 \\
\hline$\geq 150 \mathrm{~min} / \mathrm{w}$ & 1.39 & $1.2376-1.5634$ & $<0.001$ \\
\hline $\begin{array}{l}\text { Medication for } \\
\text { Hypertension }\end{array}$ & 1.16 & $1.0393-1.3005$ & 0.008 \\
\hline
\end{tabular}

95\%Cl: 95\% confidence interval; min/w: minutes per week. Source: NHS (2013). ${ }^{13}$

Table 3 Distribution of blood pressure controlled and uncontrolled participants with hypertension and the level of weekly Physical Exercise.

\begin{tabular}{|c|c|c|c|c|}
\hline & No & Yes & Total & p \\
\hline Inactive & $3,854(49.4 \%)$ & $3,943(50.6 \%)$ & 7,797 (76.5\%) & $<0.001$ \\
\hline $1-89 \mathrm{~min} / \mathrm{w}$ & 201 (44.9\%) & 247 (55.1\%) & 448 (4.4\%) & \\
\hline $90-149 \mathrm{~min} / \mathrm{w}$ & 200 (39.0\%) & $313(61.0 \%)$ & 513 (5.0\%) & \\
\hline$\geq 150 \mathrm{~min} / \mathrm{w}$ & 546 (37.9\%) & 895 (62.1\%) & $1,441(14.1 \%)$ & \\
\hline TOTAL & $4,801(47.1 \%)$ & 5,398 (52.9\%) & 10,199 (100\%) & \\
\hline
\end{tabular}

Min/w: minutes per week.

Source: NHS (2013). ${ }^{11}$ 
to a reduction of cardiovascular events and stroke ${ }^{15}$. In fact, as observed in this study, the adjusted chances of presenting CBP were higher among those who practiced any physical activity at a frequency $\geq 150 \mathrm{~min} / \mathrm{w}$. However, protective responses have already been shown to be significant at $90 \mathrm{~min} / \mathrm{w}$. It is important to point out that these responses result in 20 and $22 \%$ higher odds adjusted for CBP, in those who practiced between 90 and 149 and $150 \mathrm{~min} / \mathrm{w}$, respectively. These chances were higher than the use of hypertension medication in this same analysis.

As mentioned previously, physical activity is characterized as body movement above resting level, which comprises both labor movements and daily activities. The purpose of the activity is the accomplishment of a task, as well as leisure activities or intentional planned activities. Physical exercise is characterized as this second concept, whose ultimate goal is the accomplishment of this activity. Therefore, in the present study we analyzed the physical exercise related to leisure activity separately. Time spent on physical exercise showed a greater impact on CBP. We observed an even greater increase in the chances of $\mathrm{CBP}$ attributed to physical exercise levels compared to the levels of all physical activities. Monteiro et al. ${ }^{17}$ demonstrated that 20-30 minutes of daily regular physical activity is effective for $\mathrm{CBP}$ in some hypertensive patients. According to the results of the present analysis, we suggest that the type of physical activity in which individuals are involved may influence a higher protective effect and CBP. Physical activity characterized as physical exercise requires structure, planning, intensity, duration, frequency and continuity. Participants who performed 90 minutes per week of physical exercise or more had $42 \%$ higher adjusted chance of having CBP, reaching a level of significance. Similar responses were not obtained for the practice of regular physical activity less than 90 minutes per week. Other factors were important in CBP. In this same model, the chance of presenting $\mathrm{CBP}$ with the use of medication was significant but much lower (16\%) than with engagement in physical activity at least 90 minutes a week.

In this study, younger age groups, compared to participants aged 80 years or older, were significantly more likely to have $\mathrm{CBP}$. This phenomenon remained significant, even adjusting for activity and physical exercise. In this context, in a cohort of men aged 20 to 90 followed longitudinally for 3 to 28 years, showed that increased physical fitness reduced the incidence of hypertension over time and delayed the onset of hypertension. ${ }^{17}$

Hypertensive men presented lower chances of CBP.Although the literature observes that women have a higher prevalence of hypertension, they seem to adhere more to treatment and to lifestyle changes than men, as observed in the literature. ${ }^{18-20} \mathrm{All}$ skin colors other than white, presented lower chances of CBP, but differences are found in the literature. Hypertension is more prevalent in African Americans and with a worse prognosis in African Americans. ${ }^{21,22}$ In the present analysis the classification "other" in the skin color includes both Indian and Asian, not including Afrodescendants. ${ }^{23}$ There are few studies about the prevalence of hypertension between indigenous and Brazilian Asians. Rocha et al. ${ }^{24}$ observed an increased prevalence of hypertension, as a component of the Metabolic Syndrome, in indigenous Brazilian from the state of Rio Grande do Sul.

In the present study, other levels of marital status were compared to married participants to calculate the odds of presenting CBP. Only widowers presented lower odds of CBP than married participants, reaching an indicative degree of significance. Cesarino et al. found a higher prevalence of hypertension among married men than our analysis. ${ }^{25}$ Studies investigating this theme are still few and seem contradictory. According to the study by Holt-Lunstad et al. ${ }^{26}$ and the meta-analysis by Robles et al. ${ }^{27}$ individuals with a high-quality marriage presented lower BP levels than singles, but people who consider themselves unhappy in marriage did not get this advantage over single people. Schooling also has an important influence on $\mathrm{BP}$ control. The scientific literature reports that the highest the level of schooling, the greater opportunities for access to health services and health education. ${ }^{28}$ Corroborating with previous findings, all levels of education compared to illiteracy had a statistically higher chance of having CBP. For those with a higher level of education, the chance of control was twice as high compared to illiterates. ${ }^{28,29}$

The present study has limitations. Since it is a national health survey, the BP measurements reported by the participants were obtained by self-care, so it did not allow a more careful assessment of BP measurements by evaluators. As it is a cross-sectional study, the findings allowed us to know a possible association between physical activity levels and better $\mathrm{CBP}$ control in a Brazilian population older than 40 years.

However, it is a merit study because it has a very interesting sample and an approach little explored in other studies. In addition, it will serve for future studies to explore this information with new work and other methodologies.

\section{CONCLUSION}

According to the findings, the relevance of this study is that physical exercise was significantly associated with better $\mathrm{CBP}$ than just total PA. However, both exercise and total physical activity were significantly associated with better $\mathrm{CBP}$ compared to medication.

\section{CONFLICT OF INTERESTS}

The authors declare no conflict of interests. 


\section{REFERENCES}

1. Camargos MCS, Gonzaga MR. Viver mais e melhor? Estimativas de expectativa de vida saudável para a população brasileira. Cad Saúde Pública. 2015;31(7):1460-72. http://dx.doi.org/10.1590/0102$311 \times 00128914$

2. World Health Organization. Health statistics and information systems [Internet]. Geneva: World Health Organization; 2014 [cited on Mar. 19, 2018]. Available from: https://www.who.int/whosis/en/

3. Andrade SSDA, Stopa SR, Brito AS, Chueri PS, Szwarcwald CL, Malta DC. Prevalência de hipertensão arterial autorreferida na população brasileira: análise da Pesquisa Nacional de Saúde, 2013. Epidemiol Serv Saúde. 2015;24(2):297-304. http://dx.doi.org/10.5123/S167949742015000200012

4. Silveira JD, Scherer F, Deitos A, Dal Bosco SM. Fatores associados à hipertensão arterial sistêmica e ao estado nutricional de hipertensos inscritos no programa Hiperdia. Cad Saúde Colet. 2013;21(2):129-34. http://dx.doi.org/10.1590/S1414-462X2013000200005

5. Malachias MVB, Póvoa RMS, Nogueira AR, Souza D, Costa LS, Magalhães ME. 7th Brazilian Guideline of Arterial Hypertension: chapter 3-clinical and complementary assessment. Arq Bras Cardiol. 2016;107(3 Suppl. 3):14-7. http://dx.doi.org/10.5935/abc.20160153

6. Brazil. Ministry of Health. Health Care Secretariat. Department of Basic Attention. Strategies for the care of the person with chronic disease: systemic arterial hypertension. Brasília: Ministry of Health; 2013.

7. Caspersen CJ, Powell KE, Christenson GM. Physical activity, exercise, and physical fitness: definitions and distinctions for health-related research. Public Health Rep. 1985;100(2):126-31.

8. Instituto Brasileiro de Geografia e Estatística. Sistema IBGE de Recuperação Automática - SIDRA. Acervo XN Pesquisa Nacional de Saúde [Internet]. 2015 [cited on Oct. 24, 2019]. Available at: https:// sidra.ibge.gov.br/acervo\#/S/XN/A/Q

9. Souza-Júnior PRBD, Freitas MPSD, Antonaci GDA, Szwarcwald CL. Desenho da amostra da Pesquisa Nacional de Saúde 2013. Epidemiol Serv Saúde. 2015;24(2):207-16. http://dx.doi.org/10.5123/S167949742015000200003

10. Brook RD, Appel LJ, Rubenfire M, Ogedegbe G, Bisognano JD, Elliott WJ, et al. Beyond medications and diet: alternative approaches to lowering blood pressure. Hypertension. 2013;61(6):1360-83. https:// doi.org/10.1161/HYP.0b013e318293645f

11. Instituto Brasileiro de Geografia e Estatística. Pesquisa Nacional de Saúde [Internet]. Rio de Janeiro: Instituto Brasileiro de Geografia e Estatística; 2013 [acessado em 16 dez. 2019]. Disponível em: https:// sidra.ibge.gov.br/pesquisa/pns

12. Lackland DT, Voeks JH. Metabolic syndrome and hypertension: regular exercise as part of lifestyle management. Curr Hypertens Rep. 2014;16(11):492. https://doi.org/10.1007/s11906-014-0492-2

13. Paffenbarger RS, Jung DL, Leung RW, Hyde RT. Physical activity and hypertension: an epidemiological view. Ann Med. 1991;23(3):319-27. https://doi.org/10.3109/07853899109148067

14. Fagard RH, Cornelissen VA. Effect of exercise on blood pressure control in hypertensive patients. Eur J Cardiovasc Prev Rehabil. 2007;14(1):12-7. https://doi.org/10.1097/HJR.0b013e3280128bbb

15. Fagard RH. Physical activity, physical fitness and the incidence of hypertension. J Hypertens. 2005;23(2):265-7. https://doi. org/10.1097/00004872-200502000-00005
16. Monteiro MF, Sobral Filho DC. Exercício físico e o controle da pressão arterial. Rev Bras Med Esporte. 2004;10(6):513-9. http://dx.doi. org/10.1590/S1517-86922004000600008

17. Liu J, Sui X, Lavie CJ, Zhou H, Park YMM, Cai B, et al. Effects of cardiorespiratory fitness on blood pressure trajectory with aging in a cohort of healthy men. J Am Coll Cardiol. 2014;64(12):1245-53. https://doi.org/10.1016/j.jacc.2014.06.1184

18. Pescatello LS, Franklin BA, Fagard R, Farquhar WB, Kelley GA, Ray CA. Exercise and hypertension. Med Sci Sports Exerc. 2004;36(3):533-53. https://doi.org/10.1249/01.mss.0000115224.88514.3a

19. Silva SSBED, Oliveira SDFD, Pierin AMG. The control of hypertension in men and women: a comparative analysis. Rev Esc Enferm USP. 2016;50(1):50-8. http://dx.doi.org/10.1590/50080623420160000100007

20. Radovanovic CAT, Santos LA, Carvalho MD, Marcon SS. Hipertensão arterial e outros fatores de risco associados às doencas cardiovasculares em adultos. Rev Latino-Am Enfermagem. 2014;22(4):547-53. http:// dx.doi.org/10.1590/0104-1169.3345.2450

21. Owolabi EO, Ter Goon D, Adeniyi Ov, Seekoe E. Social epidemiology of hypertension in Buffalo City Metropolitan Municipality (BCMM) cross-sectional study of determinants of prevalence, awareness, treatment and control among South African adults. BMJ Open. 2017;7(6):e014349. https://doi.org/10.1136/bmjopen-2016014349

22. Weimann A, Dai D, Oni T. A cross-sectional and spatial analysis of the prevalence of multimorbidity and its association with socioeconomic disadvantage in South Africa: A comparison between 2008 and 2012. Soc Sci Med. 2016;163:144-56. https://doi.org/10.1016/j. socscimed.2016.06.055

23. Gravlee CC, Dressler WW, Bernard HR. Skin color, social classification, and blood pressure in southeastern Puerto Rico. Am J Public Health. 2005;95(12):2191-7. https://dx.doi. org/10.210\$/2FAJPH.2005.065615

24. Rocha AD, Bós ÂJG, Huttner É, Machado DC. Prevalência da síndrome metabólica em indígenas com mais de 40 anos no Rio Grande do Sul. Rev Panam Salud Publica. 2011;29(1):41-5.

25. Cesarino CB, Cipullo JP, Martin JFV, Ciorlia LA, Godoy MR, Cordeiro $\mathrm{JA}$, et al. Prevalência e fatores sociodemográficos em hipertensos de São José do Rio Preto. Arq Bras Cardiol. 2008;91(1):31-5. http:// dx.doi.org/10.1590/S0066-782X2008001300005

26. Holt-Lunstad J, Birmingham W, Jones BQ. Is there something unique about marriage? The relative impact of marital status, relationship quality, and network social support on ambulatory blood pressure and mental health. An Behav Med. 2008;35(2):239-44. https://doi. org/10.1007/s12160-008-9018-y

27. Robles TF, Slatcher RB, Trombello JM, McGinn MM. Marital quality and health: A meta-analytic review. Psychol Bull. 2014;140(1):140-87. https://doi.org/10.1037/a0031859

28. Banhato EFC, Guedes DV. Cognição e hipertensão: influência da escolaridade. Estud Psicol. 2011;28(2):143-51. http://dx.doi.org/10.1590/ S0103-166X2011000200002

29. Damas LVO, Nascimento MA, Nascimento Sobrinho CL. Prevalência de hipertensão e fatores associados em usuários do Programa Saúde da Família de um município do Nordeste brasileiro. Rev Bras Hipertens. 2016;23(2):39-46. 